\title{
NEW DATA ON THE VOLCANIC TUFF FROM PETREŞTII DE JOS (CLUJ DISTRICT)
}

\author{
BEDELEAN HOREA ${ }^{1}$, IVAN IOAN ${ }^{2}$, DANA POP ${ }^{1}$, \\ BEDELEAN IOAN ${ }^{1}$, PLEŞOIU GHEORGHE ${ }^{3}$
}

\begin{abstract}
New Data on the Volcanic Tuff from Petreştii de Jos (Cluj District). The present study was carried out on the cineritic interlayers from Petreştii de Jos (closed quarry from Indolului Valley), in order to present their detailed mineralogical-petrographical features. Previous work already noticed the similarity of this tuff level with Dej Tuff Complex in other areas.

The studied outcrop consists of a compact volcanic tuff interlayered with marls and tuffaceous clays. The analytical investigations: chemical analyses, X-ray diffraction, IR spectroscopy and electron microscopy reveal the nature of the diagenetic transformations dominated by zeolitization. Besides clinoptilolite, which is the typical zeolite for Dej Tuff from the Transylvanian Depression, our investigation evidenced also the presence of phillipsite. The process was stepwise: during the primary, syngenetic stage K-clinoptilolite formed, while during the late epigenetic stage Ca-phillipsite crystallized; on behalf of the latter one, Caclinoptilolite was also generated. It is worth to mention that the highest amounts of zeolites are to be found in the basal horizon, while this amount decreases in the interlayers associated with the marly-clayey levels. From genetic point of view, the lower horizon in the outcrop represents a primary fall-out tuff. The thin interlayers within the upper horizons are resedimented tuffs.

The tuff from Petreştii de Jos represents a cheap raw material located in the neighborhood of the industrial area of Turda town. For using it, only a more detailed research and the removal of the vegetal and soil layer on the top would be necessary.
\end{abstract}

KEY WORDS: volcanic tuff, clinoptilolite, phillipsite, Petreştii de Jos, Transylvanian Depression, Badenian

\section{Introduction}

The presence of the volcanic tuff interlayers within the sedimentary formations of lara post-tectonic basin was known since 1936 (O. Nitulescu). For the first time, they were petrographically characterized by I. Mârza \& L. Gaboş (1970).

The present work focused on the detailed characterization of the most important occurrence in the region, that from Petreştii de Jos. The analytical

\footnotetext{
1 "Babeş-Bolyai" University, Department of Geology, 1, Kogălniceanu St., RO-3400 ClujNapoca, Romania

${ }^{2}$ Institute for Mining Research, T. Vladimirescu St., 16, RO-3400 Cluj-Napoca, Romania

${ }^{3}$ S.C. CIMENTUL S.A. Turda
} 
investigations: chemical analyses, X-ray diffraction, IR spectroscopy and electron microscopy (SEM), reveal the nature of the diagenetic transformations dominated by zeolitization.

Besides clinoptilolite, which is the typical zeolite for Dej Tuff Complex from the Transylvanian Depression, our investigation evidenced also the presence of phillipsite.

\section{Geology of the region}

The first mentions on the stratigraphy of the "Tortonian" deposits in lara Basin, indicated also the presence of the volcanic tuffs (O. Nitulescu, 1936).

I. Mârza \& L. Gaboş (1970) identified Badenian volcanic tuffs in the outcrops from Cacova (Moga Hill), Săcel (Megheş Hill) and Petreşti ("La Butucei" Hill).

The stratigraphic position of the tuffs was established by the authors based on micropaleontological data, while the petrographical description of the cinerites was done based on polarizing microscopy, petrochemical and thermo-differential measurements. The authors conclude that the volcanic tuffs from lara Basin belong to the Dej Tuff Complex, being similar with those from Hoia Hill and Pleşca Valley (Cluj district).

Carmen Chira (2000) gives a detailed description of the stratigraphy of the Tertiary formations from Petreşti Basin, but the study was not focused on the cinerite horizons.

Our present study was carried out on the cineritic interlayers from Petreştii de Jos (Indolului Valley), in order to present their detailed mineralogical and petrographical features.

The region where the "Petreşti volcanic tuffs" (Badenian) outcrop belongs to the northwestern border of the Transylvanian Depression. The area is delimited at southeast by the crystalline-Mesozoic deposits of the Trascău Mountains and by lara sedimentary basin at northwest.

The Paleogene and Neogene deposits of Transylvanian Depression were transgressively deposited over the crystalline basement and the Mesozoic sedimentary cover (fig. 1). Among the crystalline formations, only the mesometamorphic rocks of the Baia de Arieş lithogroup (Proterozoic) outcrop in the studied area. Structurally, they form two bodies which sink towards north below younger formations (C. Chira, 2000). The body located in the neighborhood of Petreşti quarry consists of mesometamorphic rocks (gneiss, micaschist, quartzite, marble and metagabbro) which show a strong retromorphous character. 


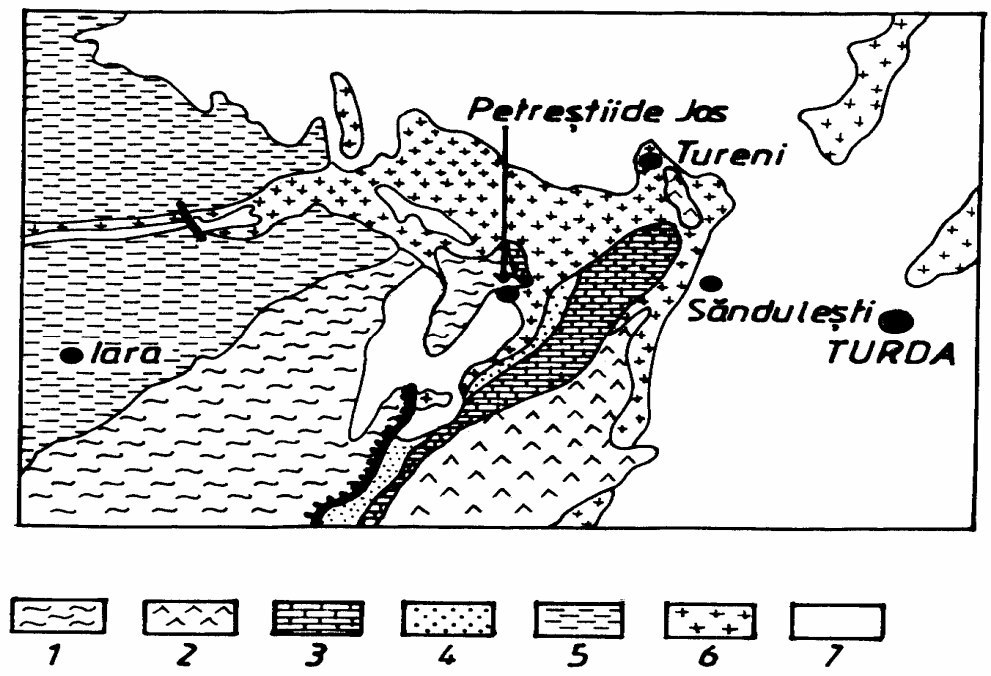

Fig. 1. - Geological sketch of the Petreştii de Jos region, sc. 1:200.000 (after M. Lupu et al., 1967)

Legend: 1. crystalline basement; 2. Jurassic (ophiolites); 3. Upper Jurassic;

4. Cretaceous; 5 . Paleogene; 6. Badenian; 7. Sarmatian

The older deposits included in the sedimentary cover are of Paleogene (Priabonian) age and they consist of clays, limestone and marls. Structurally, the sedimentary deposits form almost horizontal layers, slightly $\left(4-8^{\circ}\right)$ sinking towards the Transylvanian Depression (NE). The Neogene deposits (Miocene) consist of fossiliferous sands and oligomictic sandstone.

The most extended areas within the studied region are covered by Lower and Medium Badenian formations. Their lower part consists of conglomerates, Leitha-type limestone and marls. It is overlaid by the "Dej Tuff Formation" (Lower Badenian) represented by tuffs, tuffites, clays and marls with pyroclastic supply. Along Indolului Valley, near Petreştii de Jos, the volcanic tuff level was exploited for local purposes.

In the profile realized in the quarry the massive-compact tuff banks are interlayered with fine, friable stratified tuffs and grey or brownishreddish marls (fig. 2).

Dej Formation is lacking paleontological material; thus the age was determined according to stratigraphical arguments.

The younger deposits can be studied in the northern part of the area, where Upper Badenian (Kossovian) clays and marls interlayered with sandy-sandstone were identified.

The newest sedimentary deposits in the area are of a Sarmatian age and they consist of grey marls, sandstone, stratified interlayers of volcanic tuffs, microconglomerates and sands. The age was established on paleontological data (C. Chira, 1996). 


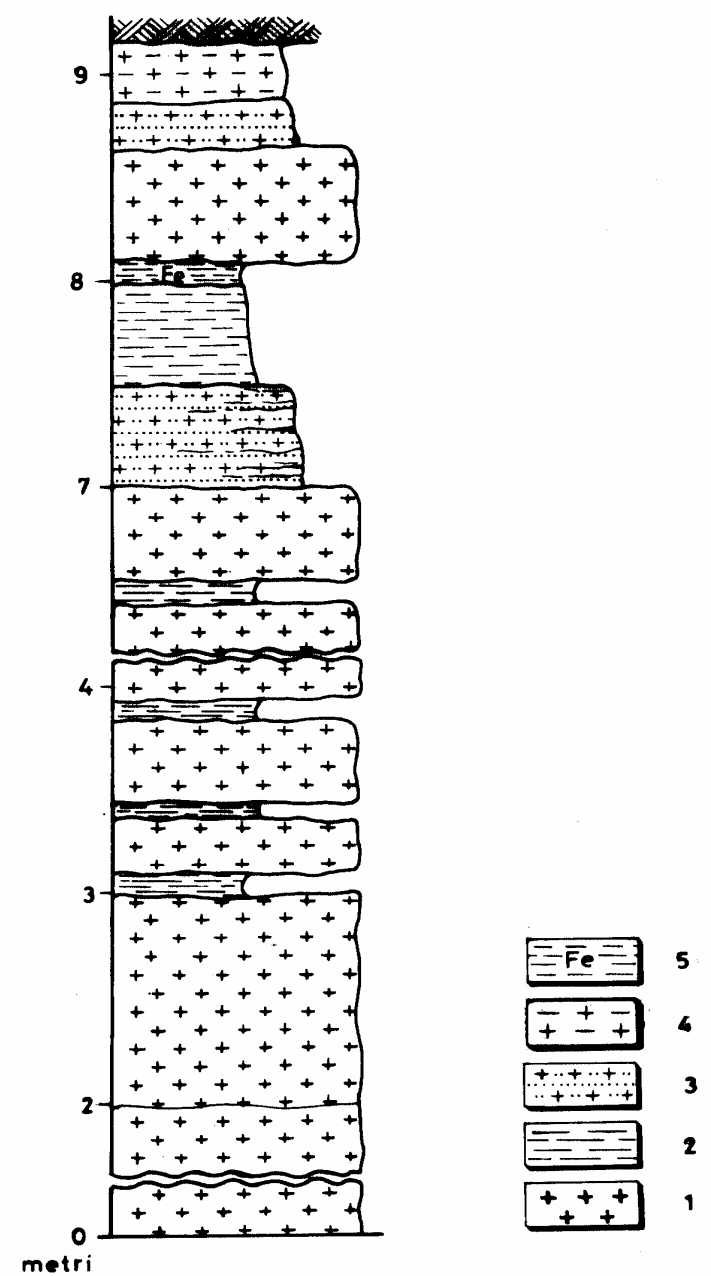

Fig. 2 - Synthetic lithological column in the volcanic tuff quarry from Petreştii de Jos - Cluj district (Romania), Indolului Valley.

Legend: 1. psamitic-aleuritic tuff in banks; 2 . clay interlayers; 3 . poorly stratified tuffitic sands; 4 . clayey tuffite; 5 . ferruginous clays interlayers.

\section{Characteristics of the tuffs from Petreştii de Jos}

\section{- Lithological characterization}

The synthetic lithological column realized in Petreşti quarry ${ }^{1}$ evidences a bank of compact volcanic tuff interlayered with marls and tuffaceous clays (fig. 2). The structure is psamitic-aleuritic and the rock is locally stratified. The

\footnotetext{
${ }^{1}$ At present the quarry is not active anymore, thus the front is mostly covered by soil and vegetation. The synthetic profile is the result of the correlation of the lithological aspects in several observation points along the old quarry 
layer is between $5-10 \mathrm{~m}$ thick, but a higher thickness is assumed for the deeper parts (where the former mining activities were located).

The upper part of the quarry is characterized by alternations of mixed rocks: tuffites, tuffitic sands, ferruginous clays $(2-5 \mathrm{~cm}$ thick or less) and compact tuffs layers ( $1 \mathrm{~m}$ thick) (fig. 2 ).

Within the tuff it is difficult to separate individual cinerite levels, because of the uniform nature of the crystalloclasts. Quartz, orthoclase, plagioclase feldspars, biotite and hornblende constitute a typical mineral assemblage for all the horizons, the only changes being their relative frequencies. In the upper horizons, the amount of crystalloclasts decreases on behalf of the vitroclastic matrix, which underwent devitrification and neoformations of a zeolitic, carbonate and argillaceous nature.

\section{- Chemical composition}

The chemical composition of the volcanic tuffs from Petreştii de Jos is comparable with that of the other Badenian volcanic tuffs from Romania (table 1).

The rock has a lower content of $\mathrm{SiO}_{2}$ and a higher $\mathrm{Al}_{2} \mathrm{O}_{3}$ content, which we connect with the process of resedimentation. During this event there was a higher supply of pelitic material.

The ratio between $R^{2+} / R^{1+}>1$, as a consequence of the sedimentological peculiarities during the formation of these tuffs.

The volcanic tuff from Petreştii de Jos shows a high cationexchange capacity. (table 1).

\section{- Petrographical and mineralogical features}

The following methods were used for the mineralogical and petrographical characterization of the Petreştii de Jos tuffs: optical microscopy, X-ray diffraction ${ }^{1}$, thermal analyse ${ }^{2}$ and IR spectroscopy ${ }^{3}$.

The detailed mineralogical composition of the deposits was studied in eight samples of tuffs but also of mixed rocks, clays or tuffaceous sands.

The thin sections of the analyzed samples were studied in parallelpolarized light, with parallel nicols and with crossed nicols.

Macroscopically, psamitic-aleuritic-pelitic varieties can be noticed. The trend is coarsening-upwards. The texture is compact and the break is usually choncoidal to flaky-irregular. The color of the tuff is white to whitegreyish, with brownish tints in the stratified interlayers; thus, the deposits have a layered aspect.

\footnotetext{
${ }^{1}$ on a DRON-3 tool unit with a Cu anticathode

2 on a DERIVATOGRAPH-1500D unit with an automatic counting system

${ }^{3}$ on a SPECORD 75 IR device
} 
Microscopically there is a great structural-compositional variety. As can be noticed in fig. 3 the pelitic tuffs from Petreştii de Jos are vitrocrystalloclastic and crystallo-vitroclastic varieties, while the psamitic and aleuritic ones are litho-vitroclastic, vitro-lithoclastic and vitro-crystallo-lithoclastic varieties (PI. I, fig. 1, 2) (fig. 3).

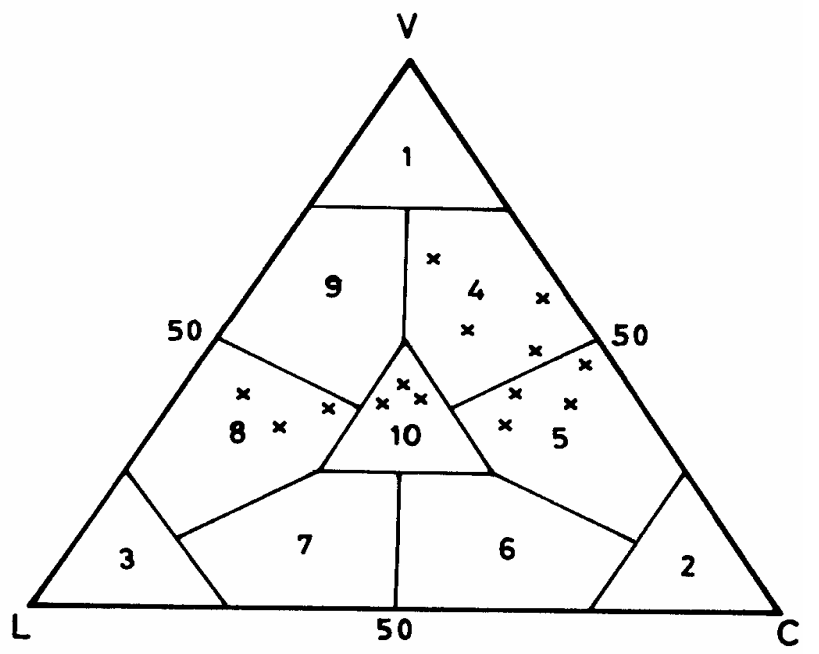

Fig. 3. - Structural-compositional varieties of the volcanic tuffs from Petreştii de Jos (Cluj district-Romania)

$\mathrm{V}=$ vitroclasts; $\mathrm{L}=$ lithoclasts; $\mathrm{C}=$ crystalloclasts

1. vitroclastic tuff; 2 . crystalloclastic tuff; 3 . lithoclastic tuff; 4 . vitro-

crystalloclastic tuff; 5 . crystallo-vitroclastic tuff; 6 . crystallo-lithoclastic tuff; 7. litho-crystalloclastic tuff; 8. litho-vitroclastic tuff; 9. crystallo-vitroclastic tuff; 10. vitro-crystallo-lithoclastic tuff.

The vitroclasts are represented by flaky-angular shards of colorless, isotropic volcanic glass, mainly transformed into zeolites. The glass forms the matrix of the psamitic and aleuritic tuffs and the ground mass of the pelitic tuffs.

The crystalloclasts consist of corroded and resorbed magmatic quartz, usually unaltered K-feldspar (orthoclase, sanidine) and Ca-Na feldspar (oligoclase and andesine) sometimes diagenetically Fe-depleted. Common hornblende and biotite, which diagenetically was partly Fe-depleted, represent the melanocrate minerals. The opaque minerals are pyrite and magnetite.

The lithoclasts are well represented in the psamitic and aleuritic varieties. They consist of rock or mineral fragments of a metamorphic or ophiolitic origin, as well as of detrital quartz. The rounded detrital quartz has both a magmatic and metamorphic origin. It proves the resedimentation of the whole tuff. The presence of feldspars is in connection with the lithoclasts (from the ophiolites) and the lithoclasts of a volcanic origin. 
The Fe oxy-hydroxides are subordinated, they form films or pseudomorphs after the melanocrate minerals. Other secondary minerals are sericite and chlorite.

Diagenetic processes

All the tuff samples show the presence of zeolites, as a result of the devitrification of the volcanic glass. Among them, besides clinoptilolite, which is dominant also, phillipsite was identified in small amounts.

The process of zeolitization - zeolitization represented a halmyrolitic diagenetic process which affected the volcanic glass (I. Bedelean, S. Stoici, 1984). All the tuff samples show the presence of zeolites; among them, besides clinoptilolite that is dominant, also phillipsite was identified in small amount.

The process was stepwise: during the primary, syngenetic stage K-clinoptilolite formed, while during the late epigenetic stage Ca-philipsite crystallized; on behalf of the latter one, Ca-clinoptilolite was also generated. This latter diagenetic process was realized according to the following relationship:

phillipsite + silica + sea water $\rightarrow$ clinoptilolite $\left[(\mathrm{Na}, \mathrm{K})_{4} \mathrm{CaAl}_{6} \mathrm{Si}_{30} \mathrm{O}_{72} \cdot 24 \mathrm{H}_{2} \mathrm{O}\right]$

It is worth to mention that the highest amount of zeolites are to be found in the basal horizon, while this amount decreases in the interlayers associated with the marly-clayey levels.

The chemical prefix (K-, Na-, Ca-) underlines the primary composition of zeolites, as well as the cation-exchange processes which they underwent. (D. S. Coombs et al., 1997)

The presence of clinoptilolite in all the samples is indicated in the XRD profiles (fig. 4) by the peaks at $8.92,3.93$ and 2. $97 \AA$ and in the thermal diagrams by the broad endothermal peak between $100^{\circ} \mathrm{C}-500^{\circ} \mathrm{C}$ with a maximum at $195^{\circ} \mathrm{C}$ (fig. 5).

The SEM images are also conclusive (PI. II, fig. 1, 2) (F. A. Mumpton, W. C. Ormsby, 1976).

The IR spectra show the presence of clinoptilolite as the main phase $\left[3760-3100 \mathrm{~cm}^{-1} ; 1200 \mathrm{~cm}^{-1} ; 1060 \mathrm{~cm}^{-1} ; 1035 \mathrm{~cm}^{-1} ; 800 \mathrm{~cm}^{-1} ; 695\right.$ $\mathrm{cm}^{-1} ; 600 \mathrm{~cm}^{-1} ; 470 \mathrm{~cm}^{-1}$ ], accompanied in smaller amounts of phillipsite $\left[1630 \mathrm{~cm}^{-1} ; 1200 \mathrm{~cm}^{-1} ; 1060 \mathrm{~cm}^{-1} ; 730 \mathrm{~cm}^{-1} ; 600 \mathrm{~cm}^{-1} ; 460 \mathrm{~cm}^{-1}\right]$ and silica (opal, quartz) [515 $\mathrm{cm}^{-1} ; 460 \mathrm{~cm}^{-1}$ ] (fig. $7, \mathrm{a}, \mathrm{b}, \mathrm{c}$ ).

Phillipsite is more difficult to be identified, due to the small amounts in the tuff. The XRD peaks at $7.84 ; 6.79 ; 3.15 ; 2.78 ; 2.55 ; 1.94 ; 1.75 \AA$ and the shape of the thermal diagram were interpreted as a result of its presence in the investigated samples. 


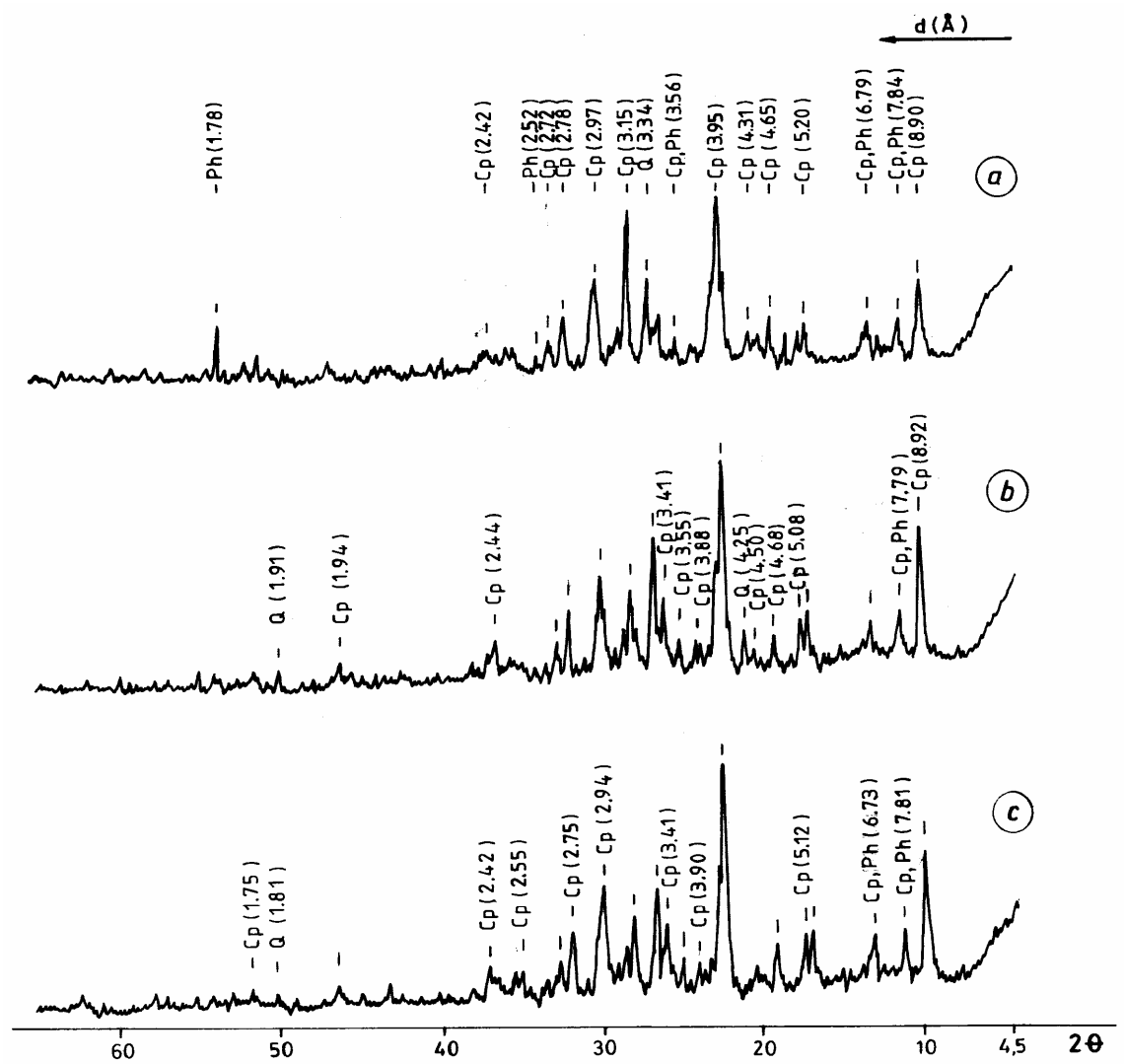

Fig. 4. - XRD analyses on volcanic tuff from Petreştii de Jos (Cluj district - Romania) a - upper part of the quarry profile; $b, c$ - lower part of the quarry profile $\mathrm{Cp}=$ clinoptilolite; $\mathrm{Ph}=$ philipsite; $\mathrm{Q}=$ quartz

Other minerals identified are secondary clay minerals, formed in alteration processes of the feldspars or during the devitrification of glass. They are represented mainly by smectites, formed in the same halmyrolitic processes as zeolites due to the transformation of volcanic glass or of the primary silicates in the lithoclasts. Illite formed exclusively as a result of the diagenetic transformation of the primary silicates in the crystalloclasts and/or lithoclasts.

The carbonates formation is more frequent in the upper horizons, due to the supply provided by the bicarbonate water of infiltration. In the same time, the presence of $\mathrm{Ca}^{2+}$ can be also connected to the structure of zeolites, where it could substitute the alkaline ions $\left(\mathrm{K}^{+}\right.$and $\left.\mathrm{Na}^{+}\right)$. These overlapping processes could explain the big differences in the alkaline and alkaline-earth ions contents in the two chemical analyses of the tuff from Petreştii de Jos (tab. 1) 

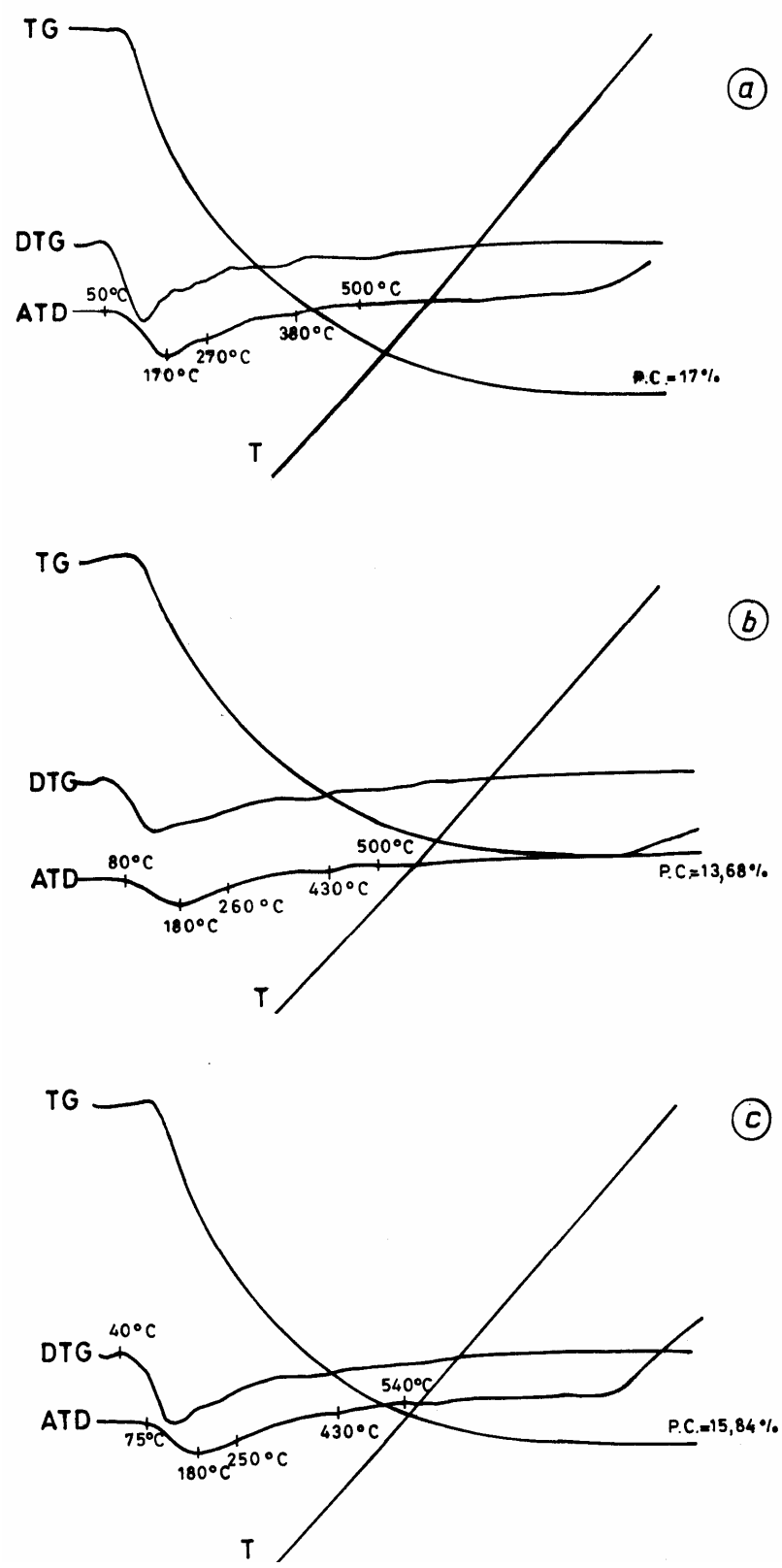

Fig. 5. - Thermal analyses on volcanic tuff from Petreştii de Jos (Cluj district - Romania) a - upper part of the quarry profile; b, c - lower part of the quarry profile

The amorphous secondary silica or crystallized silica (quartz) formed during the glass devitrification. 


\author{
Possibilities of usage \\ purposes: \\ The volcanic tuff from Petreştii de Jos could be used for the following \\ - as raw building materials for house building in the countryside; \\ over $40 \%$ of the domestic buildings in the Petreştii de Jos village \\ were already made up of the volcanic tuff from the former quarry \\ (Indolului Valley) \\ - as an additive in the cement industry (including white cement); \\ thus the cement factory in Turda could replace the tuff transported \\ from Mirsid, with a local product \\ - as a zeolite-rich raw material in the production of concentrates \\ used in animal raising or crop growing.
}

\title{
Conclusions
}

The tuff from Petreştii de Jos (Cluj district) represents a cheap raw material located in the neighborhood of the industrial area of Turda town. For using it, only a more detailed research and the removal of the vegetal and soil layer on the top would be necessary.

From a genetic point of view, the lower horizon in the outcrop, which is visible on about $5-7 \mathrm{~m}$ thick (there is no indication on its total depth) represents a primary fall-out tuff of a rhyodacitic nature. The centimetric and/or decimetric interlayers within the upper horizons are resedimented tuffs, resulted from the mixture of the pyroclastic material with the detrital (terrigenous) aleuritic and pelitic material.

\section{REFERENCES}

1. Bedelean I., Stoici S., (1984). Zeoliții. Ed. Tehn. Bucureşti, 227 p.

2. Chira Carmen, (2000), Nannoplancton calcaros şi moluşte miocene din Transilvania, Romania, Ed. Carpatica, Cluj-Napoca, 225p.

3. Coombs D.S., Alberti A., Armbruster T., Artioli G., Collela C., Galii E., Grice J. D., Liebau F., Mandarino J. A., Minato H., Nickel E. H., Passaglia E., Peacor D. R., Quartieri Simona, Rinaldi R., Ross M., Shepard R. A., Tillmans E., Vezzalini Giovana, (1997), Recommended Nomenclature for Zeolite Minerals: Report of the Subcomittee on Zeolites of the International Mineralogical Association, Commission on New Minerals and Mineral Names, The Canadian Mineralogist, vol. 35, pp. 1571-1606.

4. Lupu M., Borcoş M., Dimitrescu R., (1967), Harta Geologică a RSR, scara 1:200. 000, foaia Turda, Ed. Inst. Geol., Bucureşti

5. Mârza I., Gaboş L., (1970), Prezența tufului de Dej în Bazinul lara, Bul. Soc. St. Geol., vol. XII, p. 51-60, Bucureşti

6. Mumpton F.A., Ormsby W.C., (1976), Mophology of Zeolites in Sedimentary Rocks by Scanning Electron Microscopy, Clays and Clay Minerals, vol. 24/1, p. 1-23 
PLATE I

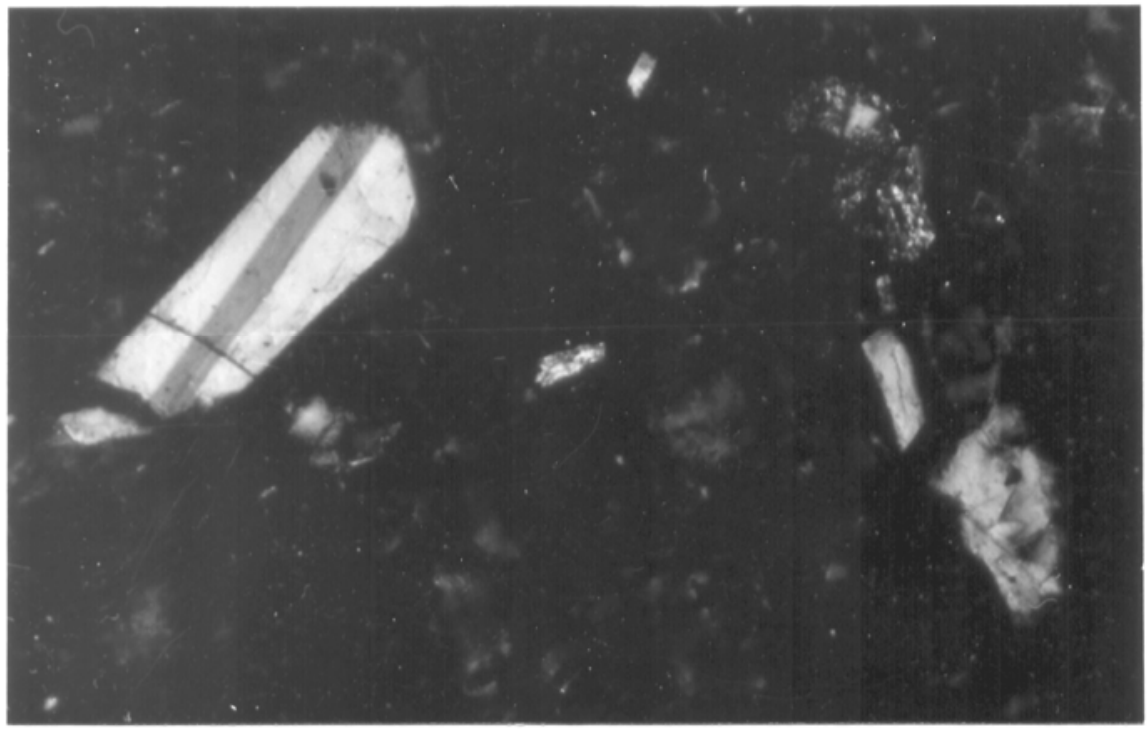

Fig. 1

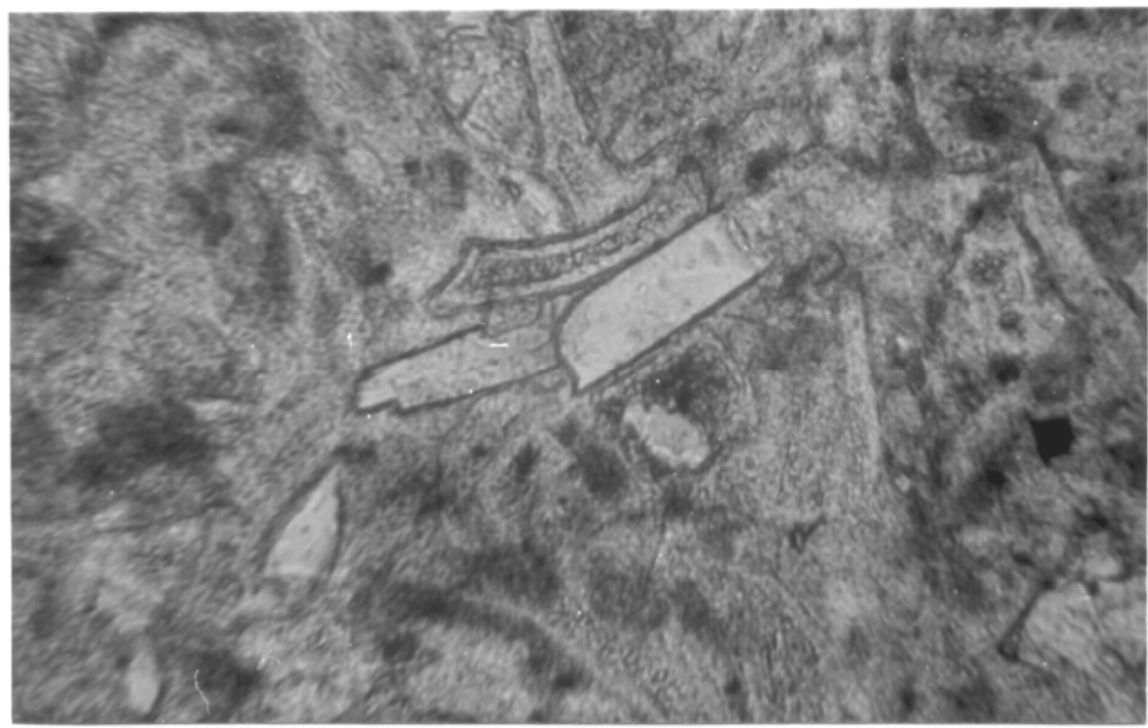

Fig. 2

Fig.1. - Optic-microscopical image of the pelitic tuff from Petreştii de Jos (Cluj district - Romania). Vitro-crystalloclastic structure. N+, 126X

Fig.2. - Zeolitized vitro-crystalloclastic tuff. Zeolitized vitroclasts can be noticed. Petreştii de Jos (Cluj district - Romania). 1N, 460X 
PLATE II
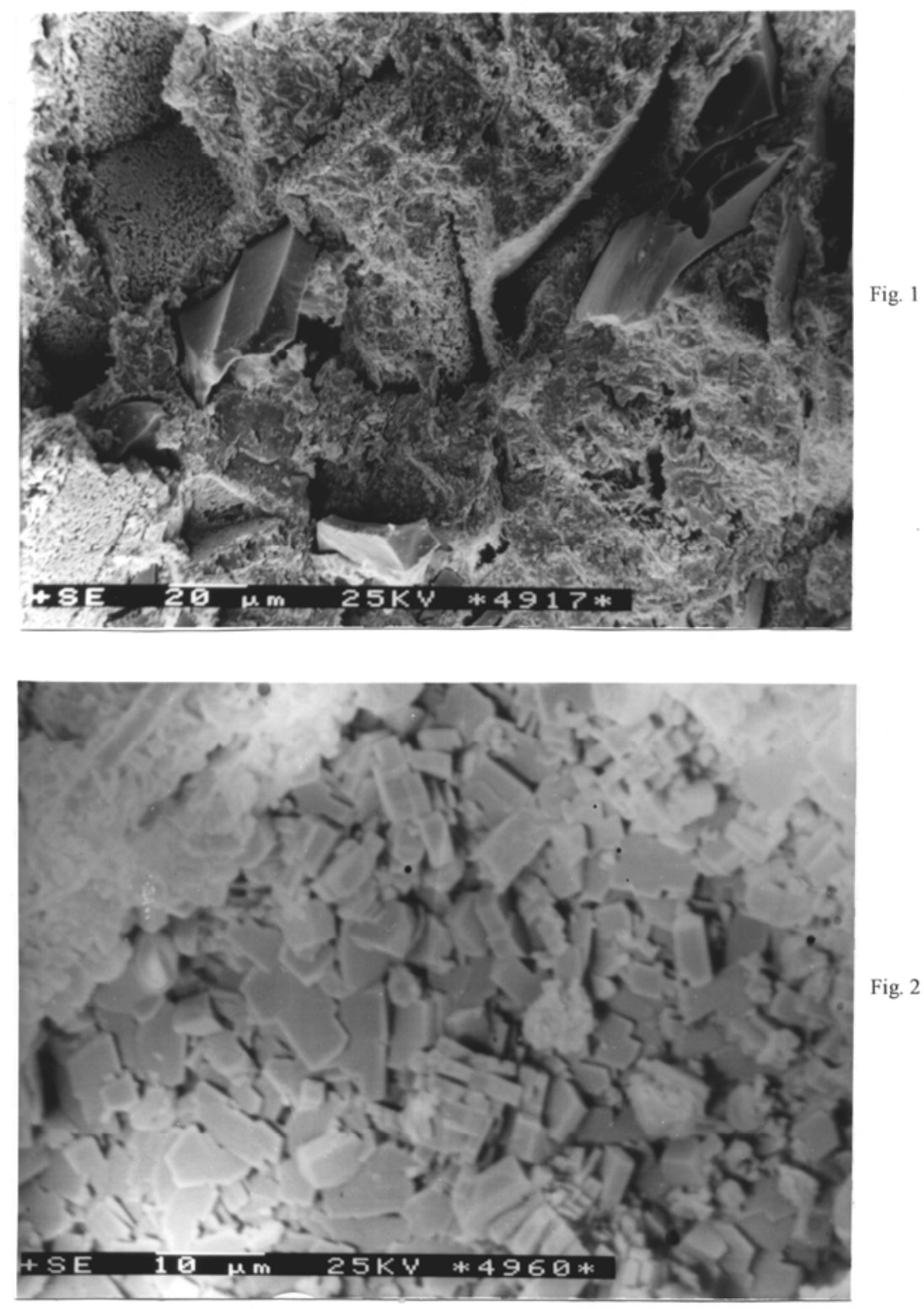

Fig. 2

Fig.1. - Electrono-microscopical features of the glassy matrix of the volcanic tuffs from Petreştii de Jos (Cluj district - Romania). The incipient stage of devitrification of the fragments of volcanic glass can be observed.

Fig.2. - Diagenetic zeolites (clinoptilolite, phillipsite) in volcanic tuff from Petreştii de Jos (Cluj district - Romania). 